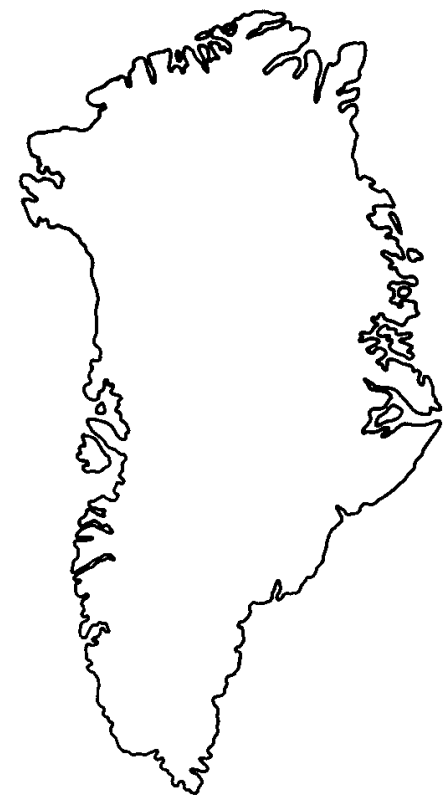

\title{
Aquilapollenites from the Late Cretaceous - Paleocene (?) of central West Greenland
}

\author{
Catherine A. Croxton
}

Four species of the fossil pollen genus Aquilapollenites (sensu lato) are reported from the Late Cretaceous (Maastrichtian) Paleocene (?) of the Nûgssuaq peninsula, central West Greenland. The West Greenland pollen assemblages may have some connection to those of Alaska, northern Canada and Scotland.

C. A. C., Robertson Research International Ltd., Tyn-y-Coed, Llanrhos, Llandudno, Gwynedd, U.K. (formerly Grønlands Geologiske Undersøgelse).

Sedimentary rocks of Cretaceous to Early Tertiary age are present on land in West Greenland between $69^{\circ}$ and $72^{\circ} \mathrm{N}$. A series of sections covering this area has been measured and sampled (Croxton, 1976; Hansen, 1976), and the samples subsequently processed for palynological investigations. Several species of Aquilapollenites (sensu lato), an angiospermous pollen of unknown botanical affinity, were recovered from Late Cretaceous and possibly Paleocene strata on the Nûgssuaq peninsula.

\section{Geological setting}

The sediments of the Nûgssuaq peninsula, described by Henderson, Rosenkrantz \& Schiener (1976), can in places be seen resting on Precambrian gneiss and on geological evidence are postulated to have a maximum thickness of 2 to $2.5 \mathrm{~km}$. These sediments are overlain by a thick sequence of Tertiary basalts.

The sedimentary facies developments vary over the area. Generally speaking there is a transition from the sandstone-shale facies of fluviatile-deltaic origin in the south-east of Nûgssuaq to a marine shale facies in the north-west.

On the Nûgssuaq peninsula the sedimentary area is defined and cut by several major faults with downthrow to the west (fig. 1). A system of faults to the east of the basin downthrows the sediments against the Precambrian; faults in the west of the basin downthrow the younger basalts against the sediments. One of the easterly system of faults reaching the north coast of Nûgssuaq at Ikorfat cuts the sediments here with a considerable downthrow to the west.

A regional dip direction to the north-east generally not exceeding $15^{\circ}$ has been observed. 


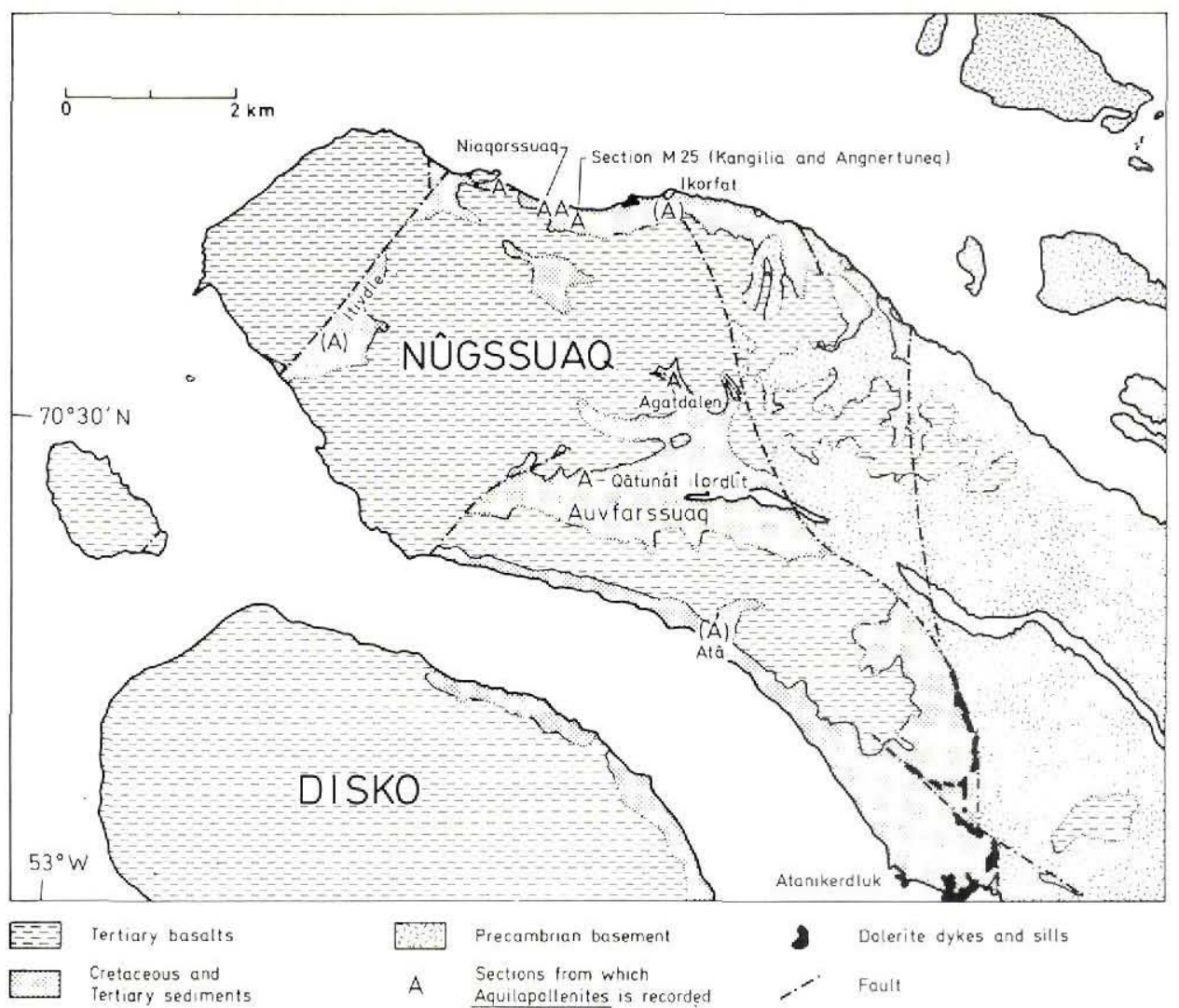

Fig. 1. The Nûgssuaq peninsula, central West Greenland, indicating sections from which Aquilapollenites is recorded.

\section{General stratigraphy}

Lithostratigraphic and biostratigraphic correlation of the sediments of the Nûgssuaq peninsula is impeded by the differing facies developments. The various lithostratigraphic units whose names recur in the literature are poorly defined and do not form a comprehensive system. Koch (1964) clarifies the chiefly nonmarine formations. A generalised biostratigraphic division of the sediments which draws from both macrofossil evidence (summarised by Henderson et al., 1976) and from recent palynostratigraphical studies (Croxton, 1978 ) is summarised below.

The oldest strata recognised in the area occur on the north coast of Nûgssuaq to the east of Ikorfat where the base of the sequence, a series of thinly bedded sandstones and shales is in sedimentary contact with Precambrian basement. (This lower part of the sequence is known as the Kome Formation). Typical Early Cretaceous palynological assemblages have been recovered throughout the sequence with at least the topmost part of the upper sequence, a predominantly sandstone sequence overlying a siltstone-shale dominated facies, as young as Middle or Late Albian. 
The Cretaceous strata of the south coast of Nugssuaq (Atane Formation) and the central valley of Nûgssuaq, comprising sequences of sandstones and shales with coal seams, range from Late Albian to Campanian in age, the older strata being located in the south-eastern Atanikerdluk area.

On the north coast of Nûgssuaq, to the west of Ikorfat, the Cretaceous marine shales are Campanian to Maastrichtian in age. The strata in the Itivdle valley area to the west appear, on palynological evidence, to be equivalent in part to this sequence.

On the Nûgssuaq peninsula a Paleocene sequence occurs above the Cretaceous. A discontinuous coarse conglomerate, possibly a submarine channel fill, occurs within the marine shales of the north coast of Nûgssuaq and has been considered to separate strata of Maastrichtian and Paleocene ages (Rosenkrantz, 1970). (The shale series above the conglomerate is known as the Kangilia Formation). A conglomerate in the central Nûgssuaq area (the 'Oyster-ammonite Conglomerate') is considered equivalent to the north coast conglomerate and rests in Agatdalen unconformably on Campanian strata. This conglomerate is overlain by shale and sandstone sequences considered to be Paleocene in age. (These are known in Agatdalen as the Kangilia and Agatdal Formations). On the south coast of Nugssuaq the unconformity is often marked by a large channel infill sandstone cutting down into the Cretaceous strata. This is overlain by a thick shale unit and higher sandstone units known as the Upper Atanikerdluk Formation.

\section{Sections including Aquilapollenites}

Several species of Aquilapollenites are recorded in West Greenland. Their occurrence is restricted to assemblages recovered from strata considered Late Cretaceous and Paleocene in age from sections on Nugssuaq. These are located in two principal areas: the north coast of Nûgssuaq, between Itivdle and Ikorfat, and the Agatdalen area of the central valley of Nûgssuaq. In addition one section in Auvfarssuaq has yielded Aquilapollenites and questionable occurrences are recorded from Atâ and Itivdle (fig. 1).

Of the two main areas, the thickest continuous sequence occurs on the north coast of Nûgssuaq. In Agatdalen the strata are located at the head of a valley where tributaries join the main stream. The few sections are all less than $100 \mathrm{~m}$ thick. Their field relationships are not obvious and made more confusing by a NNW-SSE fault. This report only discusses those species of Aquilapollenites in assemblages recovered from the north coast area.

\section{North coast of Nûgssuaq}

From Itivdle to Ikorfat, a series of predominantly dark shales with concretions are continuously (but often poorly) exposed. The topographical setting poses some problems. The shale sequences occur on steep slopes up to an altitude of $800 \mathrm{~m}$. Gravity slumping is very common and not always obvious in the field.

A composite section (designated M25) was measured and sampled by J. M. Hansen (1976) in the gullies of Kangilia and Angnertuneq (figs 1,2). Two offsets were made where lithological units were believed to have been followed and therefore this sample series is thought to be a true stratigraphic sequence and representative of the marine sequence in the north coast area. 


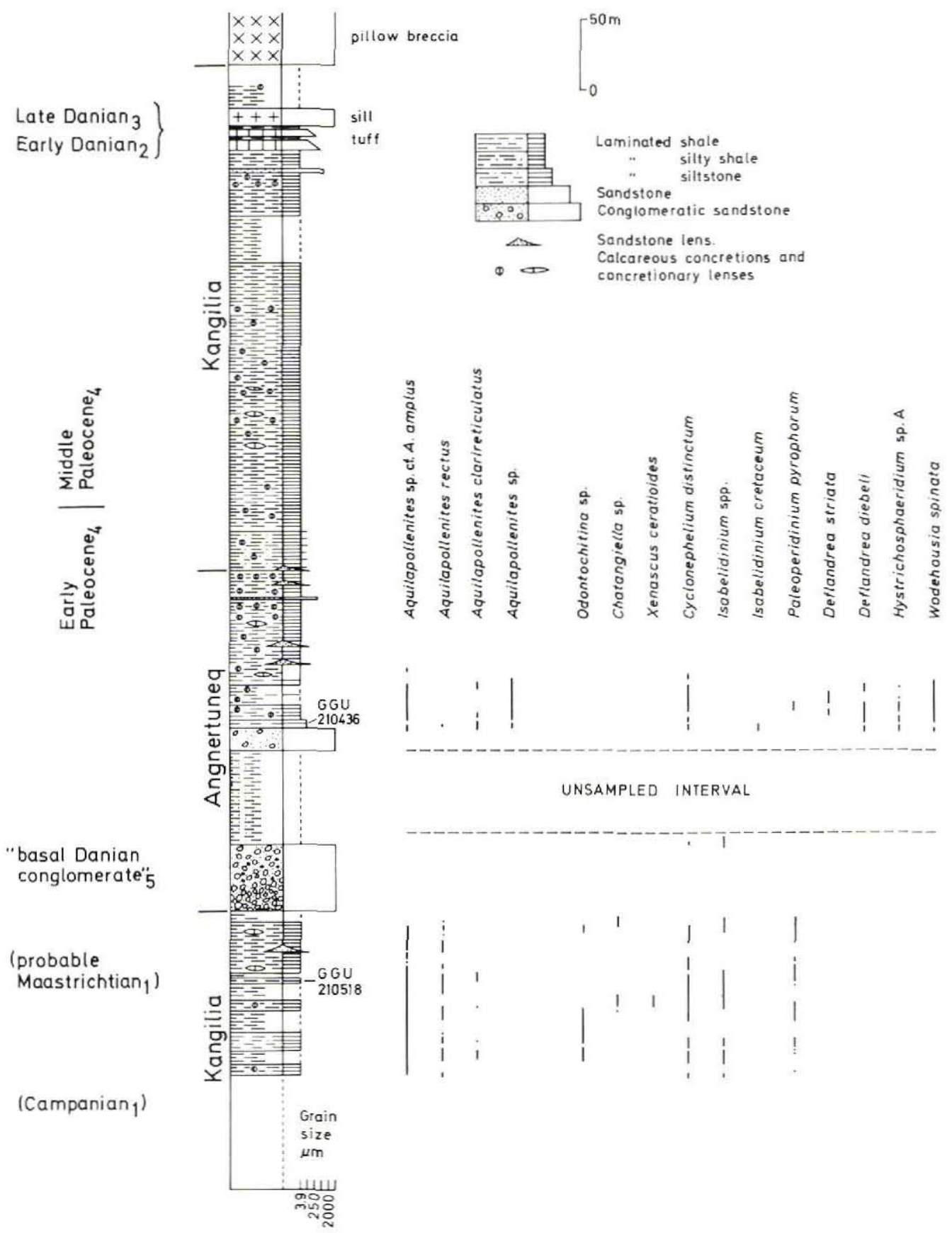

Fig. 2. Section M25, a composite section measured at Kangilia and Angnertuneq on the northern coast of Nûgssuaq (fig. 1), showing distribution of Aquilapollenites and selected palynomorphs. Section measured and sampled by J. M. Hansen in 1975 (Hansen, 1976). Aquilapollenites has not been recorded above the middle of the section. The two section intervals measured at Kangilia occur between altitudes $123-235 \mathrm{~m}$ and $445-800 \mathrm{~m}$ above sea level, respectively; the Angnertuneq section at altitudes $320-480 \mathrm{~m}$ above sea level. Subscripts accompanying age estimates on the left of the figure indicate the information source: 1, Birkelund (1965); 2, Floris (1972); 3, Jürgensen \& Mikkelsen (1974); 4, J. M. Hansen, personal communication; 5, Rosenkrantz (1970). 
Palynological preparations have been made both by the writer and by J. M. Hansen following standard techniques with $\mathrm{HCl}, \mathrm{HF}$ and $\mathrm{HNO}_{3}$. The writer used zinc bromide separations to concentrate the palynomorphs while J. M. Hansen frequently employed an alternative separation technique to concentrate dinoflagellate cysts (Hansen \& Gudmundsson, 1979). Preparations of 90 samples throughout section M25 were examined in detail.

\section{Biostratigraphy of Section M25}

Some macrofossil and nannofossil evidence is available from this locality (fig. 2). Birkelund (1965) recorded ammonites at Angnertuneq 103-110 m above sea level which she referred to the uppermost Campanian, while higher in the same gully at $165-200 \mathrm{~m}$ a species of probable Maastrichtian age was found. Rosenkrantz (1970) stated that the $50 \mathrm{~m}$ conglomerate occurring within the shale sequences between Kangilia and Niaqorssuaq is basal Danian and described fossils including gastropods, pelecypods, corals, echinoderms and nautiloids from much higher in the sequence. A fish fauna from this higher level was considered by Bendix-Almgreen (1969) to be Senonian to Middle Danian in age. Corals from tuff beds at approximately $740 \mathrm{~m}$ above sea level in Kangilia and from a level from 750-760 m altitude in Angnertuneq were considered by Floris (1972) to be Early Danian. However, Jürgensen \& Mikkelsen (1974) studied coccoliths from these tuffs and assigned a Late Danian age.

J. M. Hansen (personal communication) on the basis of dinoflagellate cysts considers the strata from the conglomerate to approximately $480 \mathrm{~m}$ altitude in section M25 (Kangilia) to be Early Paleocene and the section above this to be Middle Paleocene.

\section{Palynological evidence from strata including Aquilapollenites}

Aquilapollenites has been recovered from a restricted part of section M25, including the strata below the conglomerate and also an interval above the conglomerate up to approximately $415 \mathrm{~m}$ altitude in Angnertuneq. The distribution of selected palynomorphs throughout the interval where Aquilapollenites is recorded is shown in fig. 2.

From the strata below the conglomerate the assemblages recovered include Paleoperidinium pyrophorum (Ehrenberg) Sarjeant (Plate 5, figs 6,7) which has a known range of Maastrichtian to Early Paleocene (Williams \& Bujak, 1977). Species of Odontochitina are, however, also commonly recorded. This genus is not considered to occur above the Campanian (Williams \& Lentin, 1975; Denison \& Fisher, 1977). Chatangiella sp. and Xenascus ceratioides (Deflandre) Lentin \& Williams, also generally considered pre-Maastrichtian, are present in the same interval.

The conglomerate certainly marks a horizon where there is a readily observable change in the palynomorph assemblages. Of the selected palynomorphs plotted on fig. 2 five forms have their first appearance above this level. Isabelidinium spp. are common below the conglomerate, but Isabelidinium cretaceum (Cookson) Lentin \& Williams (Plate 4, fig. 3 ) only occurs above. Its known range is Maastrichtian with possible extension into the Paleocene (Williams \& Lentin, 1975; Denison \& Fisher, 1977). Deflandrea striata Drugg and Deflandrea diebeli Alberti (Plate 4, fig. 6; Plate 5, fig. 1) both have known ranges from 
Maastrichtian upwards into the Early Paleocene (Williams \& Lentin, 1975; Caro, 1977; Denison \& Fisher, 1977; Williams \& Bujak, 1977). Hystrichosphaeridium sp. A Williams \& Bujak, 1977 (Plate 5, figs 3-5) described from the Labrador shelf does not occur in strata younger than Middle Paleocene but its range in Labrador is probably Campanian to Middle Paleocene (G. L. Williams, personal communication). Wodehousia spinata Stanley (Plate 4, figs 1,2) was noted by Leffingwell et al. (1970) to occur only in the Maastrichtian in North America, although a form believed to be synonymous is recorded from both Maastrichtian and Paleocene strata of Siberia by Samoilovitch (1961). A form occurring commonly below and above the conglomerate, Cyclonephelium distinctum Deflandre \& Cookson (Plate 4, figs $4,5)$ was given a range from Valanginian to Campanian by Williams \& Lentin (1975) but has also been observed in the Maastrichtian of Labrador by Williams (personal communication).

On the basis of the above evidence the strata below the conglomerate appear unlikely to be older than Maastrichtian when the frequent occurrence of Paleoperidinium pyrophorum throughout the interval is considered. The commonly recorded pre-Maastrichtian forms are most probably reworked.

Strata above the conglomerate could be either Maastrichtian or Early Paleocene. Many of the recorded forms first appear at this level and have ranges which are known to extend into the Early Tertiary, although no palynomorph has been observed which to the writer's knowledge is known to only occur in strata of Paleocene or younger age. However, Paleocene forms such as Deflandrea speciosa Alberti and Alisocysta circumtabulata (Drugg) Stover \& Evitt have been observed higher in the section. Wodehousia spinata (most commonly Maastrichtian) in section M25 occurs only in the interval of strata immediately above the conglomerate. This interval may possibly represent a zone within the Paleocene with reworking of forms from different (? younger) Maastrichtian palynological assemblages than those from below the conglomerate, but the numbers and state of preservation of many of the palynomorphs give no indication that they have been recycled. However, such a phenomenon is recorded by Evitt (1973) from the base of the Danian Kincaid Formation in Texas.

No conclusive statement can be made on current palynological evidence as to whether this interval of strata above the conglomerate represents:

1. Paleocene strata enclosing palynomorph assemblages of earliest Paleocene age with Paleocene examples of forms whose ranges extend from the Upper Cretaceous into the Early Tertiary.

2. Maastrichtian strata enclosing younger Maastrichtian palynomorph assemblages than those recovered from below the conglomerate.

3. Paleocene strata enclosing a largely reworked palynomorph assemblage from different (? younger) Maastrichtian strata than those below the conglomerate.

The macrofossil and nannofossil evidence does not give direct support for any of these possibilities as those horizons indicating Danian ages are much higher in the section and there is no published evidence for the conglomerate to be basal Danian. Maastrichtian strata could well occur above as well as below the conglomerate, the latter marking a discontinuity within a Maastrichtian sequence. However, the three possibilities based on the palynological evidence are, in the writer's opinion, listed in the order of probability. 


\section{Distribution of the species of Aquilapollenites in section M25}

Four species of Aquilapollenites have been recognised in section M25 and their distribution is displayed on fig. 2.

Aquilapollenites sp. cf. A. amplus occurs both below and above the conglomerate but is more numerous in assemblages from below. A. rectus is common in assemblages from below the conglomerate but only one questionable occurrence is recorded from those above. $A$. clarireticulatus occurs infrequently throughout the interval under consideration. Aquilapollenites sp. occurs only in the interval above the conglomerate.

Three species of Aquilapollenites are therefore recorded from strata of the north coast of Nûgssuaq which are confirmed to be Maastrichtian in age on palynological evidence. Since it was not possible to reach a conclusion concerning the age of the strata above the conglomerate, none of the Aquilapollenites occurrences recorded here can be conclusively stated to be Paleocene. However one species (Aquilapollenites sp.) has its first appearance in this interval and another ( $A$. rectus) is apparently no longer present. Hence the contrast in other palynomorph suites is also reflected in the Aquilapollenites species. Nevertheless, even if it could be demonstrated that the interval of strata above the conglomerate was Paleocene in age, the possibility of Aquilapollenites grains themselves being reworked from Late Cretaceous strata could not be ruled out.

\section{Systematic descriptions \\ ANGIOSPERMAE Incertae sedis \\ Genus Aquilapollenites Rouse, 1957, Funkhouser, 1961}

Type species: Aquilapollenites quadrilobus Rouse, 1957

Terminology used in referring to various parts of Aquilapollenites follows Srivastava (1969) and Srivastava \& Rouse (1970). Dimensions of the four species described are shown on Tables $1 \& 2$.

Aquilapollenites sp. cf. A. amplus Stanley, 1961

Plate 1 , figs $1-6$

1961. Aquilapollenites amplus Stanley, pp. 342-346, pl. 1, 2 \& 3

Remarks. This is the most common of the species of Aquilapollenites recovered from West Greenland material. An assessment of the size range and variation is based on 67 specimens (55 in equatorial aspect, 10 in polar aspect and 2 in oblique aspect) recorded in an exceptionally well preserved (Campanian) assemblage recovered from a reworked concretion from the 'Oyster-ammonite Conglomerate' of Agatdalen.

The size range of the polar axis is readily comparable to that quoted by Stanley (1961) for A. amplus. The length of the equatorial diameter is always equal to or greater than that of the polar axis. The West Greenland form is often subisopolar rather than strictly isopolar. The developed polar projection is broadly rounded while the smaller polar projection is often flattened. The breadth of the two polar projections is generally similar, but these dimensions are somewhat narrower than those quoted by Stanley for the diameter of the 
Table 1. Dimensions of Aquilapollenites sp. cf. A. amplus and Aquilapollenites rectus

\begin{tabular}{|c|c|c|c|c|c|c|c|c|c|c|}
\hline \multirow[b]{3}{*}{ Size ranges } & \multicolumn{5}{|c|}{$\begin{array}{l}\text { Aquilapollenites sp. } \\
\text { cf. } A \text {. amplus }\end{array}$} & \multicolumn{5}{|c|}{ A. rectus } \\
\hline & \multicolumn{3}{|c|}{ Limits \& Mean } & \multirow{2}{*}{$\sigma$} & \multirow[t]{2}{*}{ No. } & \multicolumn{3}{|c|}{ Limits \& Mean } & \multirow[t]{2}{*}{$\sigma$} & \multirow[t]{2}{*}{ No. } \\
\hline & & $\mu \mathrm{m}$ & & & & & $\mu \mathrm{m}$ & & & \\
\hline Length of polar axis & (42) & 53.0 & $(65)$ & 5.2 & 53 & (22) & 29.2 & (36) & 4.1 & 25 \\
\hline $\begin{array}{l}\text { Length of equatorial } \\
\text { diameter }\end{array}$ & (45) & 57.9 & $(70)$ & 5.6 & 55 & (27) & 33.3 & (40) & 3.5 & 19 \\
\hline $\begin{array}{l}\text { Length of developed } \\
\text { polar projection }\end{array}$ & (15) & 19.9 & (25) & 2.8 & 51 & (6) & 9.7 & (12) & 2.0 & 24 \\
\hline $\begin{array}{l}\text { Length of reduced } \\
\text { polar projection }\end{array}$ & (11) & 15.9 & $(22)$ & 2.1 & 51 & ( 2$)$ & 5.9 & ( 9 ) & 1.7 & 23 \\
\hline $\begin{array}{l}\text { Length of equatorial } \\
\text { projection }\end{array}$ & (19) & 24.2 & $(30)$ & 2.6 & 51 & (9) & 12.2 & (15) & 1.6 & 24 \\
\hline $\begin{array}{l}\text { Breadth of developed } \\
\text { polar projection } \\
\text { Breadth of reduced }\end{array}$ & ( 8 ) & 11.4 & (15) & 1.5 & 55 & ( 6$)$ & 10.4 & (15) & 2.3 & 22 \\
\hline polar projection & $(7)$ & 11.2 & (15) & 1.8 & 53 & ( 3$)$ & 7.8 & (11) & 2.1 & 20 \\
\hline $\begin{array}{l}\text { Breadth of equatorial } \\
\text { projection }\end{array}$ & (11) & 15.0 & $(18)$ & 1.4 & 52 & ( 8$)$ & 12.4 & (18) & 2.0 & 24 \\
\hline $\begin{array}{l}\text { Ratios } \\
\text { Equatorial diameter/ }\end{array}$ & & & & & & & & & & \\
\hline $\begin{array}{l}\text { Polar axis } \\
\text { Length of developed } \\
\text { polar projection/ } \\
\text { Length of reduced }\end{array}$ & $(1.0)$ & 1.1 & $(1.4)$ & 0.1 & 42 & $(1.0)$ & 1.2 & (1.4) & 0.1 & 16 \\
\hline $\begin{array}{l}\text { polar projection } \\
\text { Length of equatorial } \\
\text { projection/Length } \\
\text { of developed polar }\end{array}$ & $(1.0)$ & 1.3 & (1.9) & 0.2 & 50 & $(1.2)$ & 1.9 & $(5.5)$ & 1.0 & 21 \\
\hline projection & $(1.0)$ & 1.2 & (1.5) & 0.1 & 48 & $(1.0)$ & 1.3 & $(2.2)$ & 0.3 & 22 \\
\hline $\begin{array}{l}\text { Breadth of equatorial } \\
\text { projection/Breadth } \\
\text { of developed polar } \\
\text { projection }\end{array}$ & $(1.0)$ & 1.3 & $(2.0)$ & 0.2 & 52 & $(0.9)$ & 1.3 & (2.0) & 0.3 & 20 \\
\hline
\end{tabular}

body of $A$. amplus. The neck region of the polar projections is in most specimens somewhat restricted.

The equatorial projections are always at least equal to and usually greater in length and breadth than the polar projections. In equatorial view they have broadly rounded ends. The colpi are meridional across the apices of the equatorial projections and in the West Greenland form commonly extend from a third to a half of the length of the equatorial projections. 
The two-layered exine is from 1 to $2.5 \mu \mathrm{m}$ thick on the polar projections and much thinner on the equatorial projections. The boomerang-shaped endexinal thickenings are up to $3.5 \mu \mathrm{m}$ thick in the thickest part. The reticulum in $A$. sp. cf. A. amplus, formed by the fused columnar ektexinal elements, is fine over most of the grain. However, in many specimens the reticulum in the neck region of the polar projections can be much coarser with lumina up to $1.5 \mu \mathrm{m}$. The spinules ornamenting the polar projections are approximately $1 \mu$ $m$ in length, most numerous in the apical region and directed polewards. The spinules which ornament the apical region of the equatorial projections are aligned parallel to the equatorial axis.

Occurrences in West Greenland. Maastrichtian and Paleocene(?) of the north coast of Nûgssuaq. Campanian of the Agatdalen area. Reworked Campanian and Maastrichtian concretions in the 'Oysterammonite Conglomerate', Agatdalen. Paleocene of Agatdalen (possibly derived). ?Maastrichtian in Qâtunat ilordlît.

Aquilapollenites rectus Tschudy, 1969

Plate 2, figs 1-6

1969. Aquilapollenites rectus Tschudy, p. A10-A11, pl. 12, figs 1-13; pl. 13, figs 4 \& 9

Remarks. An assessment of the size range and variation of the West Greenland material is based on 29 specimens ( 26 in equatorial aspect, 1 in polar aspect and 2 in oblique aspect) recovered from one sample of Section M25 (Kangilia) from approximately $50 \mathrm{~m}$ below the 'basal Danian conglomerate'.

The size range of the West Greenland specimens has a lower limit for the length of the polar axis and a somewhat wider range for the (greater) equatorial diameter when compared to the size ranges cited by B. D. Tschudy (1969). The West Greenland specimens are subisopolar with the developed polar projection broadly rounded while the smaller projection, of which the breadth is generally less, may be somewhat conical in shape.

The equatorial projections, broadly rounded in equatorial view, are equal to or greater in length than the developed polar projection and are generally broader. The colpi (only observed on one specimen) appear to extend the full length of the equatorial projections as described by Tschudy.

The two-layered exine has been observed to be 1 to $2 \mu \mathrm{m}$ thick on the polar projections and the axillary endexinal thickenings from 2.5 to $4 \mu \mathrm{m}$ thick in the thickest part. The spinules, distributed over the microreticulate-appearing surface of the grain, are approximately $1 \mu \mathrm{m}$ in length. Baculae are often arranged round the periphery of the colpi at the apices of the equatorial projections.

Occurrences in West Greenland. Maastrichtian of the north coast of Nûgssuaq.

Aquilapollenites clarireticulatus (Samoilovitch, 1965) Tschudy, 1969

Plate 3, figs 1-3

1965. Integricorpus clarireticulatus Samoilovitch, p. 123-124; pl. 1

1969. Aquilapollenites clarireticulatus (Samoilovitch) Tschudy, p. A6-A7, pl. 2 \& 3

Remarks. This species occurs infrequently in the West Greenland material and the following 
Table 2. Dimensions of Aquilapollenites clarireticulatus and Aquilapollenites sp.

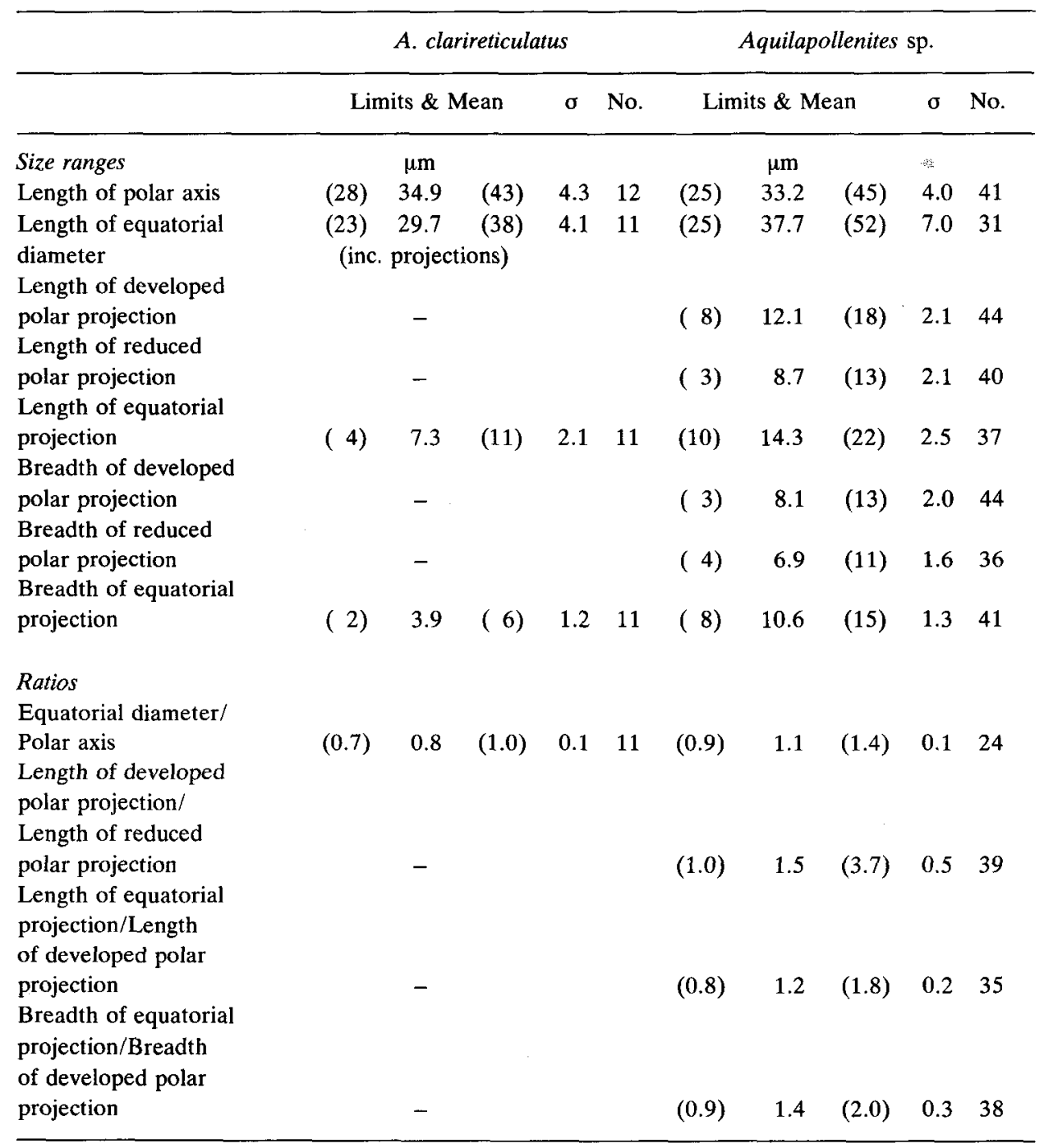

comments are based on 12 specimens in equatorial aspect recovered from one sample of section M25 (Angnertuneq) from approximately $80 \mathrm{~m}$ above the 'basal Danian conglomerate'.

The size range of the West Greenland specimens is comparable to the material described by B. D. Tschudy (1969) and, likewise, the specimens are smaller than those described by Samoilovitch (1965). The West Greenland specimens are isopolar to subisopolar with one polar projection often being broadly rounded while the other is more conical in shape.

The equatorial projections are generally V-shaped. The colpi, as described by Tschudy, extend onto the body for three-quarters of the distance to the poles. 
The two-layered exine is 1 to $2 \mu \mathrm{m}$ thick and the endexinal thickenings up to 2 to $3 \mu \mathrm{m}$ thick in the thickest part. The lumina of the reticulum, which merges into the striations of the equatorial belt, have been observed to be approximately $1 \mu \mathrm{m}$, but in some specimens are much smaller.

Occurrences in West Greenland. Maastrichtian and Paleocene(?) of the north coast of Nûgssuaq.

\section{Aquilapollenites sp.}

Plate 3, figs 4-9

Remarks. This form occurs in restricted intervals in the West Greenland strata. It has not been identified and the preservation of specimens recorded is considered too poor for the erection of a new species. The assessment of size range and variation is based on 51 specimens (50 in equatorial aspect, 1 in oblique aspect) recovered from one sample of section M25 (Angnertuneq) from approximately $80 \mathrm{~m}$ above the 'basal Danian conglomerate'.

The length of the equatorial diameter is almost always greater than the length of the polar axis. The form is subisopolar. The developed polar projection is generally broadly rounded while the reduced polar projection may in an individual specimen be much narrower and peg-like.

The equatorial projections, broadly rounded in equatorial view, are generally greater in length and breadth than the developed polar projections but in a few specimens are less. The colpi are meridional across the apices of the equatorial projections and appear to be restricted to the apical region.

The exine is two-layered and 0.5 to $1.0 \mu \mathrm{m}$ thick. The ektexine is pilate giving a microgranular appearance to the grains. Axillary endexinal thickenings appear to be present (their absence in many specimens may be due to the poor preservation) and are up to $2 \mu \mathrm{m}$ thick in the thickest part.

Occurrences in West Greenland. Paleocene(?) of the north coast of Nûgssuaq.

\section{Comments on the occurrence of Aquilapollenites in West Greenland}

This record of the occurrence of Aquilapollenites from the Late Cretaceous and possibly Early Paleocene of West Greenland is of significance when the world-wide restricted stratigraphic and geographic distribution of this, and other Late Cretaceous pollen genera is considered (R. H. Tschudy, 1970; Muller, 1970; Stanley, 1970; Hughes, 1973).

The West Greenland assemblages with Aquilapollenites are comparable to assemblages known from Alaska and northern Canada. A. rectus and $A$. clarireticulatus both occurring in West Greenland were described by B. D. Tschudy (1969) from Alaska while $A$. clarireticulatus was recorded among other Aquilapollenites species by Brideaux (1971) and McIntyre (1974) from locations in the District of Mackenzie, N. W. T. Aquilapollenites species were also recorded by Rouse \& Srivastava (1972) from the northern Yukon and Felix \& Burbridge (1973) from Ellef Ringnes Island.

Wodehousia occurs in association with Aquilapollenites in West Greenland. Other less frequently observed pollen groups include Proteacidites and very occasional representatives 
of the Normapolles group. McIntyre (1974) recorded these three forms from the District of Mackenzie N. W. T. Wodehousia is also recorded from Alaska (Tabbert, 1967), the northern Yukon (Rouse \& Srivastava, 1972), northern Somerset Island (Hopkins, 1971) and Ellef Ringnes Island (Felix \& Burbridge, 1973).

R. H. Tschudy (1970) in discussing the dissimilarities in the pollen floras of eastern and western North America postulated a migration of Aquilapollenites-producing plants from Asia across the Bering Strait. The basis of his argument was that Aquilapollenites is recorded from the Aptian in Siberia while in North America no records of the genus are known from earlier than the Santonian. Stanley (1970) also speculated on a migration of Aquilapollenites-producing plants via Alaska and through northern and eastern Canada to explain the occurrence of Aquilapollenites in Scotland (Martin, 1968) where the European Normapolles flora (Goczan et al., 1967) might otherwise have been expected to occur. The Scottish occurrence is in strata that are most likely between Maastrichtian and Early Eocene in age.

Although only a preliminary assessment has to date been made of the earliest occurrence of Aquilapollenites in West Greenland it is not thought to occur in strata older than Campanian in age. When the similarity between the Alaskan/northern Canadian and the West Greenland Late Cretaceous pollen assemblages is considered it would seem quite possible that there is some connection between them. The plant producing Aquilapollenites could have 'migrated' from Asia through northern North America to West Greenland. Further, especially when the Cretaceous world map reconstructed by Smith, Briden \& Drewry (1973) and used by Hughes (1973) to plot the distribution of Normapolles and Aquilapollenites is considered, it is possible that the Scottish (?later) occurrence is the most easterly 'outpost' of this direction of migration.

\section{References}

Bendix-Almgreen, S. E. 1969: Notes on the Upper Cretaceous and Lower Tertiary fish faunas of northern West Greenland. Bull. geol. Soc. Denmark 19, 204-217.

Birkelund, T. 1965: Ammonites from the Upper Cretaceous of West Greenland. Bull. Gronlands geol. Unders. 56 (also Meddr. Grønland 179, 7) 192 pp.

Brideaux, W. W. 1971: Palynologic evidence for a very late Cretaceous age of Little Bear and East Fork Formations, District of Mackenzie. Pap. geol. Surv. Can. 71-1, (B) 86-91.

Caro, Y. 1977: In Distribution of biostratigraphically diagnostic dinocysts and miospores from the Northwestern European Continental Shelf and adjacent areas. Int. Paly. Coll. 1977, 22-27. Trondheim: Continental Shelf Institute.

Croxton, C. A. 1976: Sampling of measured sections for palynological and other investigations between $69^{\circ}$ and $72^{\circ} \mathrm{N}$, central West Greenland. Rapp. Grønlands geol. Unders. 80, 36-39.

Croxton, C. A. 1978: Report of field work undertaken between $69^{\circ}$ and $72^{\circ} \mathrm{N}$, central West Greenland in 1975 with preliminary palynological results. Unpubl. int. GGU report, $99 \mathrm{pp}$.

Denison, C. M. \& Fisher, M. J. 1977: In Distribution of biostratigraphically diagnostic dinocysts and miospores from the Northwestern European Continental Shelf and adjacent areas. Int. Paly. Coll. 1977, 17-21. Trondheim: Continental Shelf Institute.

Evitt, W. R. 1973: Maestrichtian Aquilapollenites in Texas, Maryland, and New Jersey. Geosci. Man. 7, 31-38.

Felix, C. J. \& Burbridge, P. P. 1973: A Maestrichtian age microflora from Arctic Canada. Geosci. Man. 7, 1-29.

Floris, S. 1972: Scleractinian corals from the Upper Cretaceous and Lower Tertiary of Nûgssuaq, West Greenland. Bull. Grønlands geol. Unders. 100 (also Meddr Grønland 196, 1) 132 pp. 
Goczan, F., Groot, J. J., Krutzsch, W. \& Pacltova, B. 1967: Die Gattungen des "Stemma Normapolles Pflug 1953b" (Angiospermae). Paläont. Abh. 2B (3), 429-539.

Hansen, J. M. 1976: Microplankton and sedimentological studies in the Nûgssuaq and Disko region, central West Greenland. Rapp. Grønlands geol. Unders. 80, 39-42.

Hansen, J. M. \& Gudmundsson, L. 1979: A method for separation of acid-insoluble microfossils from organic debris. Micropalaeontology, 25, 130-170.

Henderson, G., Rosenkrantz, A. \& Schiener, E. J. 1976: Cretaceous-Tertiary sedimentary rocks of West Greenland. In Escher, A. \& Watt, W. S. (edit.) Geology of Greenland, 341-362. Copenhagen: Geological Survey of Greenland.

Hopkins, W. S. 1971: Cretaceous and/or Tertiary rocks, northern Somerset Island, District of Franklin. Pap. geol. Surv. Can. 71-1, (B), 102-104.

Hughes, N. F. 1973: Mesozoic and Tertiary distributions and problems of Land-plant evolution. Spec. Pap. Palaeont. 12, 188-198.

Jürgensen, T. \& Mikkelsen, N. 1974: Coccoliths from volcanic sediments (Danian) in Nûgssuaq, West Greenland. Bull. geol. Soc. Denmark 23, 225-230.

Koch, B. E. 1964: Review of fossil floras and non-marine deposits of West Greenland. Bull. geol. Soc. Amer. 75, 535-548.

Leffingwell, H. A., Larson, D. A. \& Valencia, M. J. 1970: A study of the fossil pollen Wodehouseia spinata. Bull. Can. petrol. Geol. 18, 238-262.

McIntyre, D. J. 1974: Palynology of an Upper Cretaceous section, Horton River, District of Mackenzie, N. W. T. Pap. geol. Surv. Can. 74-14, 57 pp.

Martin, A. R. H. 1968: Aquilapollenites in the British Isles. Palaeontology 11, 549-553.

Muller, J. 1970: Palynological evidence on early differentiation of angiosperms. Biol. Rev. 45, 417-450.

Rosenkrantz, A. 1970: Marine Upper Cretaceous and lowermost Tertiary deposits in West Greenland. Meddr Dansk geol. Foren. 19, 406-453.

Rouse, G. E. \& Srivastava, S. K. 1972: Palynological zonation of Cretaceous and early Tertiary rocks of the Bonnet Plume Formation, northeastern Yukon, Canada. Can. J. Earth Sci. 9, 1163-1179.

Samoilovitch, S. R. 1961: Pollen and spores of western Siberia, Jurassic-Paleocene. Trudy Vses. Neft. Nauchno-Issled. Geol. Razved. Inst. 177, 352 pp. (in Russian).

Samoilovitch, S. R. 1965: Pollen of new species of Upper Cretaceous angiosperm plants of Yakutia. Trudy Vses. Neft. Nauchno-Issled. Geol. Razved. Inst. 239, 121-141 (in Russian).

Smith, A. G., Briden, J. C. \& Drewry, G. E. 1973: Phanerozoic world maps. Spec. pap. Palaeont. 12, $1-42$.

Srivastava, S. K. 1969: New spinulose Aquilapollenites spp. from the Edmonton Formation (Maestrichtian), Alberta, Canada. Can. J. Earth Sci. 6, 133-144.

Srivastava, S. K. \& Rouse, G. E. 1970: Systematic revision of Aquilapollenites Rouse 1957. Can. J. Bot. 48, 1591-1601.

Stanley, E. A. 1961: The fossil pollen genus Aquilapollenites. Pollen Spores 3, 329-352.

Stanley, E. A. 1970: The stratigraphical, biogeographical, paleoantecological and evolutionary significance of the fossil pollen group Triprojectacites. Bull. Georgia Acad. Sci. 28, 1-44.

Tabbert, R. L. 1967: Upper Cretaceous pollen and spores from the Ivishak River area, Arctic Alaska Abst. Rev. Paleobot. Palynol. 2, 8-9.

Tschudy, B. D. 1969: Species of Aquilapollenites and Fibulapollis from two Upper Cretaceous localities in Alaska. Prof. pap. U.S. geol. Surv. 643-A, 17 pp.

Tschudy, R. H. 1970: Palynology of the Cretaceous-Tertiary boundary in the northern Rocky Mountains and Mississippi Embayment regions. Spec. Pap. geol. Soc. Am. 127, 65-111.

Williams, G. L. \& Bujak, P. J. 1977: Cenozoic palynostratigraphy of offshore Eastern Canada. Am. Assoc. Strat. Palynol., Contrib. 5A, 14-47.

Williams, G. L. \& Lentin, J. K. 1975: Stratigraphic range charts. Selected Cretaceous dinoflagellates. Am. Assoc. Strat. Palynol., Contrib. 4, 65-71. 


\section{Plates}

Plates 1-4, bright field illumination.

Plate 5, phase contrast.

All stage co-ordinates are from Leitz Orthdux II microscope 863327, Geological Survey of Greenland.

All photographs were taken on Kodak Panatomic-X film using a Leitz Orthomat automatic camera.

MGUH denotes the type collection of the Geological Museum, Copenhagen.

\section{Plate 1}

Magnification $\times 1000$

Aquilapollenites sp. cf. A. amplus Stanley from GGU 210639, concretion from the 'Oyster-ammonite Conglomerate', Agatdalen.

Fig. 1. Equatorial view. (MGUH 15093, Prep. G258/F8 23.2, 103.1).

Fig. 2. Equatorial view showing aperture. (MGUH 15094, Prep. G258/F8, 38.0, 105.1).

Fig. 3. Equatorial view showing coarser reticulum on neck of polar projections. (MGUH 15095, Prep. G258/F8, 45.6, 98.7).

Fig. 4. Equatorial view showing spinules on polar projection. (MGUH 15096, Prep. G258/F8, 22.3, 97.5).

Fig. 5. Equatorial/oblique view. (MGUH 15097, Prep. G258/F8, 46.2, 112.6).

Fig. 6. Polar view. (MGUH 15098, Prep. G258/F8, 39.2, 104.2). 

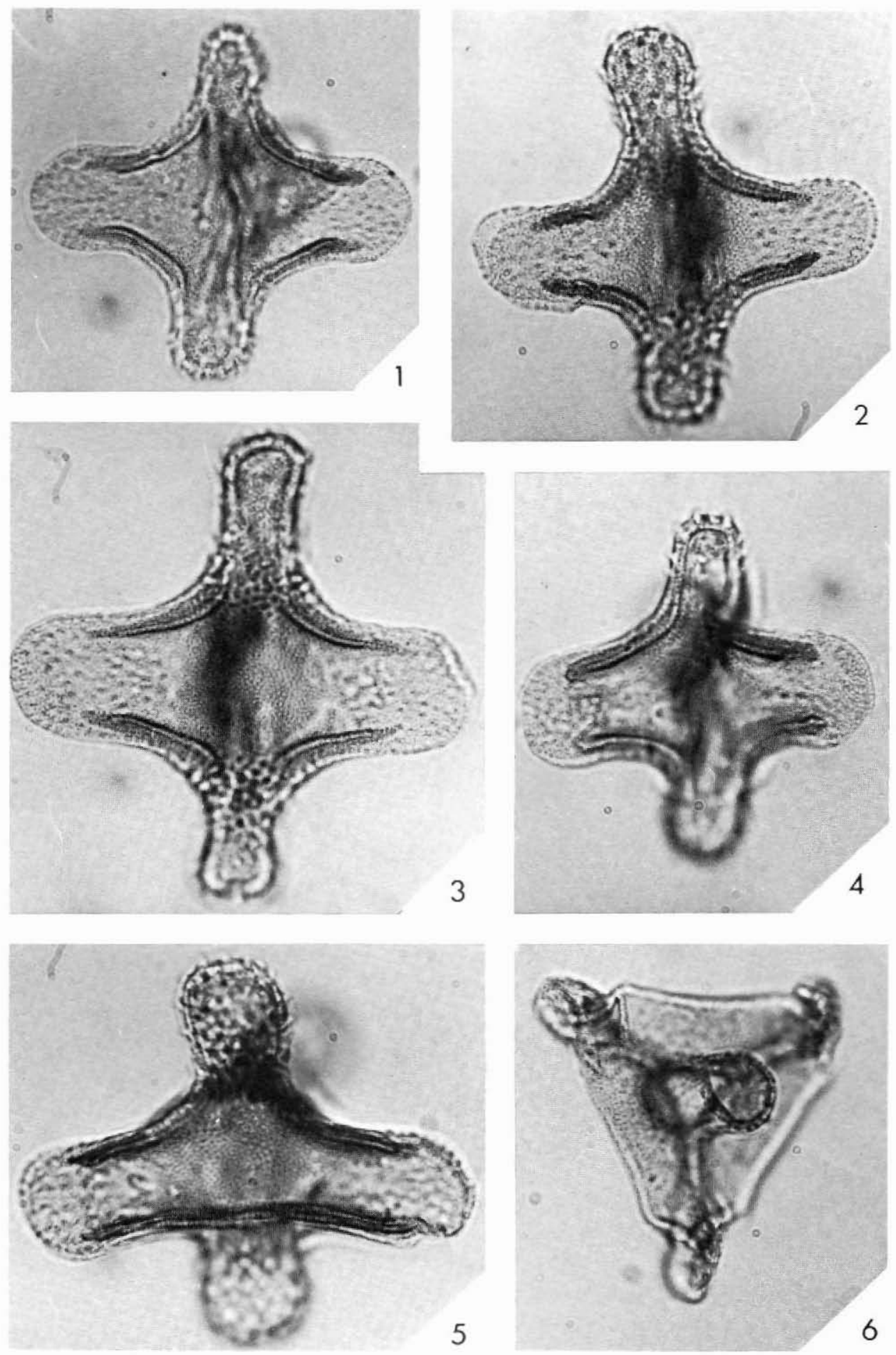


\section{Plate 2}

\section{Magnification $\times 1000$}

Aquilapollenites rectus Tschudy from GGU 210518, shale from section M25 (Kangilia), north coast of Nûgssuaq.

Fig. 1. Equatorial view. (MGUH 15099, Prep. T670/3, 38.9, 101.1).

Fig. 2. Equatorial view. (MGUH 15100, Prep. T670/5, 42.2, 94.3).

Fig. 3. Equatorial view. (MGUH 15101, Prep. T670/6, 48.7, 102.8).

Fig. 4. Equatorial view. (MGUH 15102, Prep. T670/6, 41.2, 95.3).

Fig. 5. Equatorial view. (MGUH 15103, Prep. T670/5, 46.8, 97.8).

Fig. 6. Polar view showing colpi along equatorial projections. (MGUH 15104, Prep. T670/3, 43.7, 101.5). 

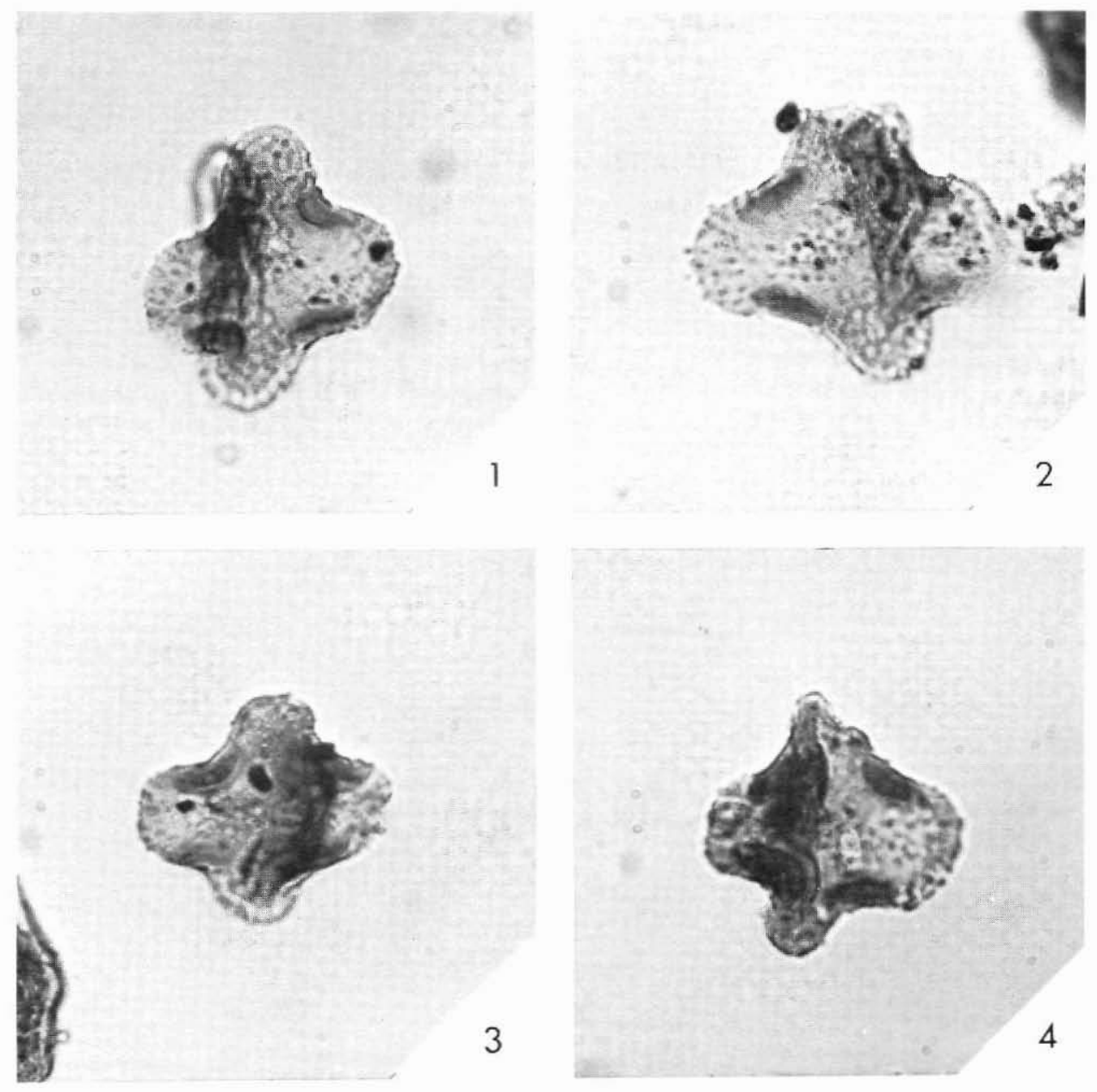

3
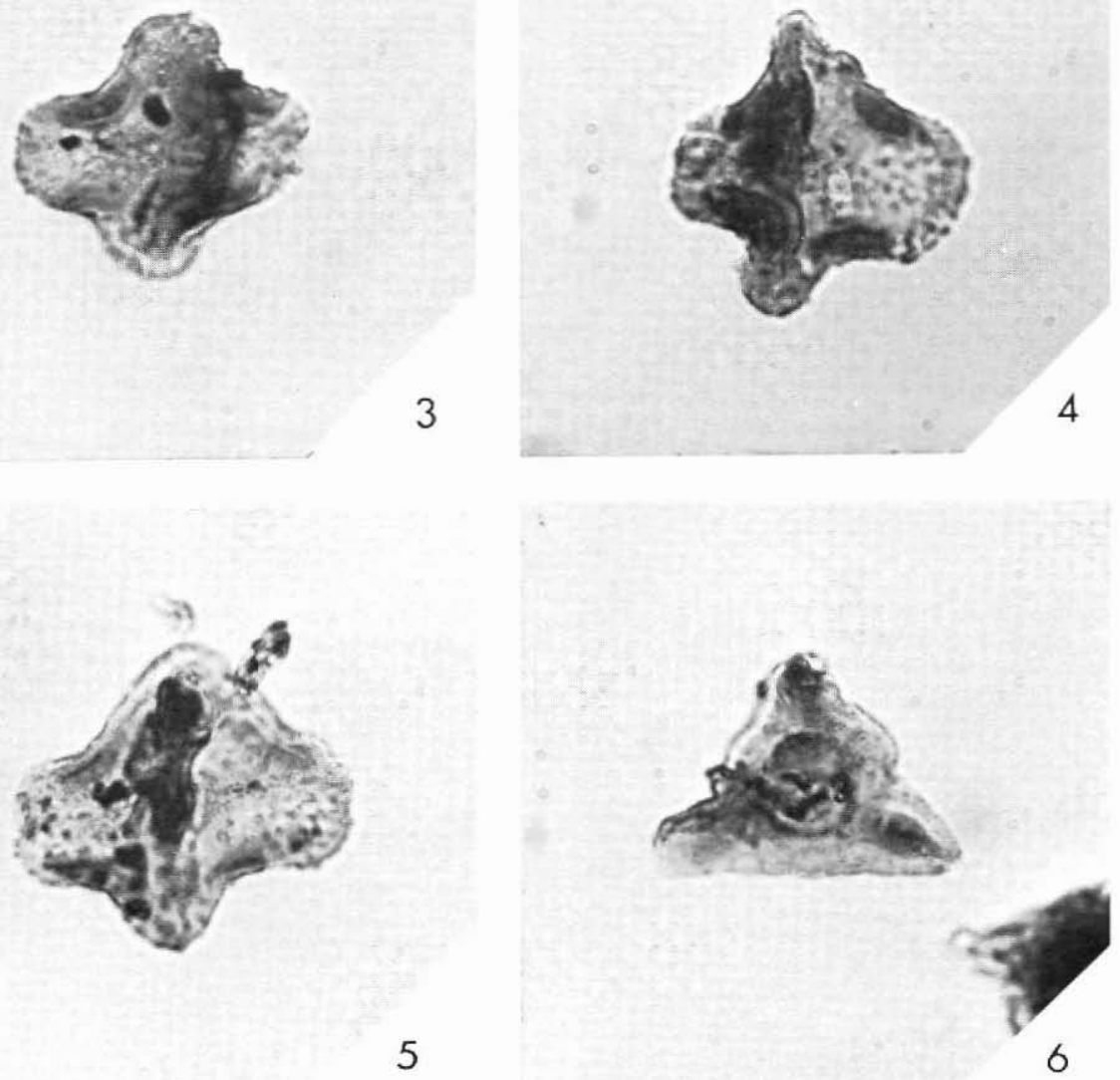


\section{Plate 3}

Magnification $\times 1000$

Aquilapollenites clarireticulatus (Samoilovitch) Tschudy from GGU 210436, shale from section M25 (Angnertuneq), north coast of Nûgssuaq.

Fig. 1. Equatorial view. (MGUH 15105, T630/7, 39.3, 98.9).

Fig. 2. Equatorial view showing equatorial furrows. (MGUH 15106, T630/3, 27.0, 105.0).

Fig. 3. Equatorial view showing colpus. (MGUH 15107, T630/7, 19.7, 97.0).

Aquilapollenites sp. from GGU 210436.

Fig. 4. Equatorial view. (MGUH 15108, T630/5, 28.0, 113.9).

Fig. 5. Equatorial view. (MGUH 15109, T630/6, 32.2, 101.1).

Fig. 6. Equatorial view. (MGUH 15110, T630/6, 25.8, 103.2).

Fig. 7. Equatorial view. (MGUH 15111, T630/5, 37.2, 100.2).

Fig. 8. Equatorial view. (MGUH 15112, T630/7, 22.8, 103.6).

Fig. 9. Oblique view. (MGUH 15113, T630/6, 28.9, 101.1). 

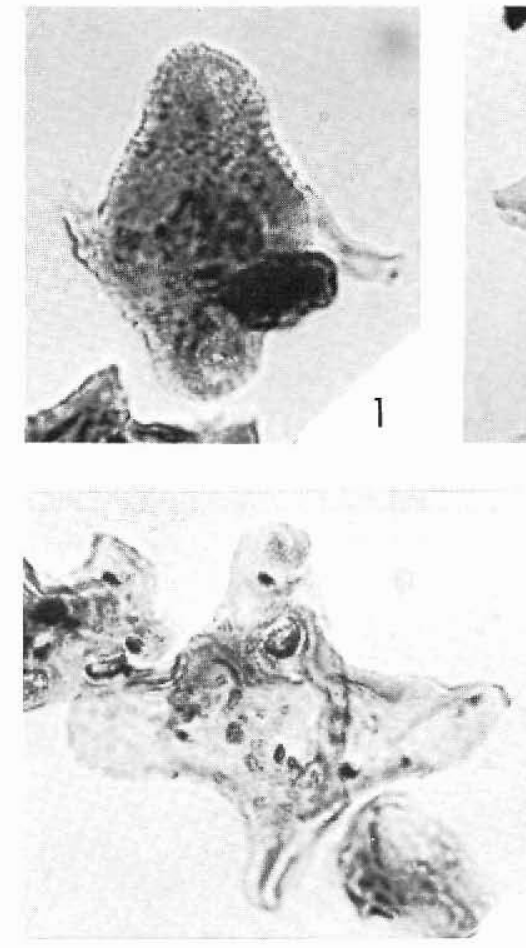

4
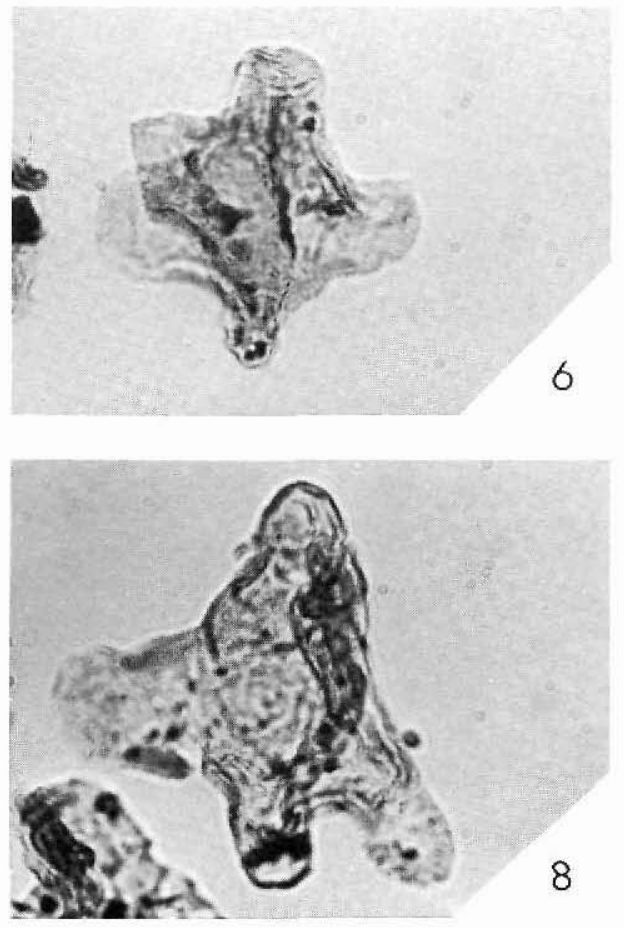

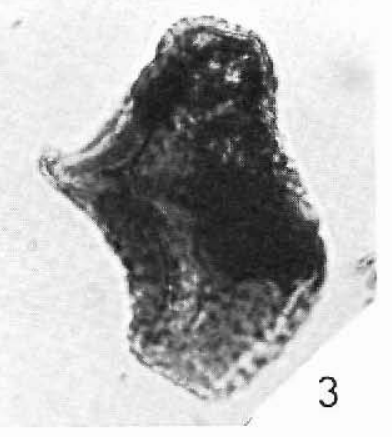

$\square$

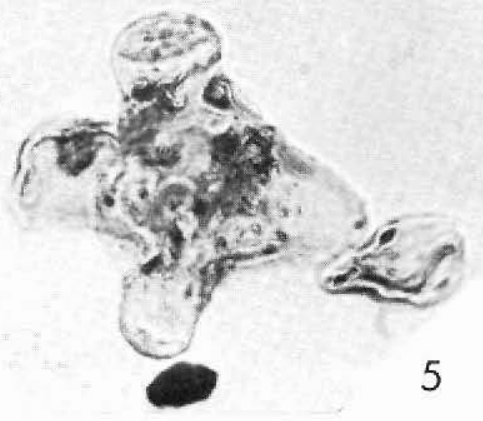

2
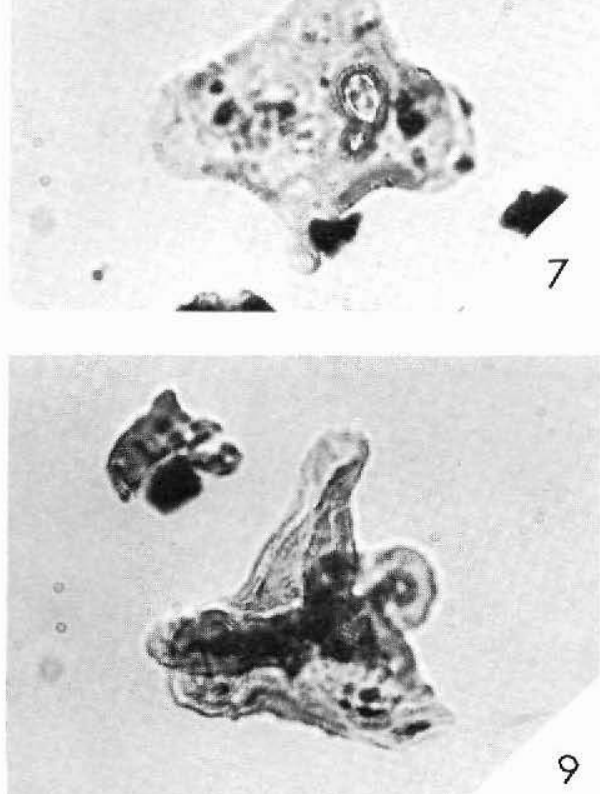


\section{Plate 4}

Magnification: Figs 1-5, $\times 1000$, Fig. $6, \times 500$

Illustrations of selected palynomorphs.

Wodehousia spinata Stanley from GGU 210436, shale from section M25 (Angnertuneq), north coast of Nûgssuaq.

Fig. 1. (MGUH 15114, T630/3, 40.6, 99.1).

Fig. 2. (MGUH 15115, T630/6, 20.2, 96.3).

Isabelidinium cretaceum (Cookson) Lentin \& Williams from GGU 210436.

Fig. 3. (MGUH 15116, T630/6, 45.1, 105.3).

Cyclonephelium distinctum Deflandre \& Cookson from GGU 210640, concretion from the 'Oysterammonite Conglomerate', Agatdalen.

Fig. 4. (MGUH 15117, G259/F8, 43.7, 100.8).

Fig. 5. (MGUH 15118, G259/F8, 26.7, 109.2).

Deflandrea diebeli Alberti from GGU 210640.

Fig. 6. (MGUH 15119, G259/F8, 27.6, 98.7). 

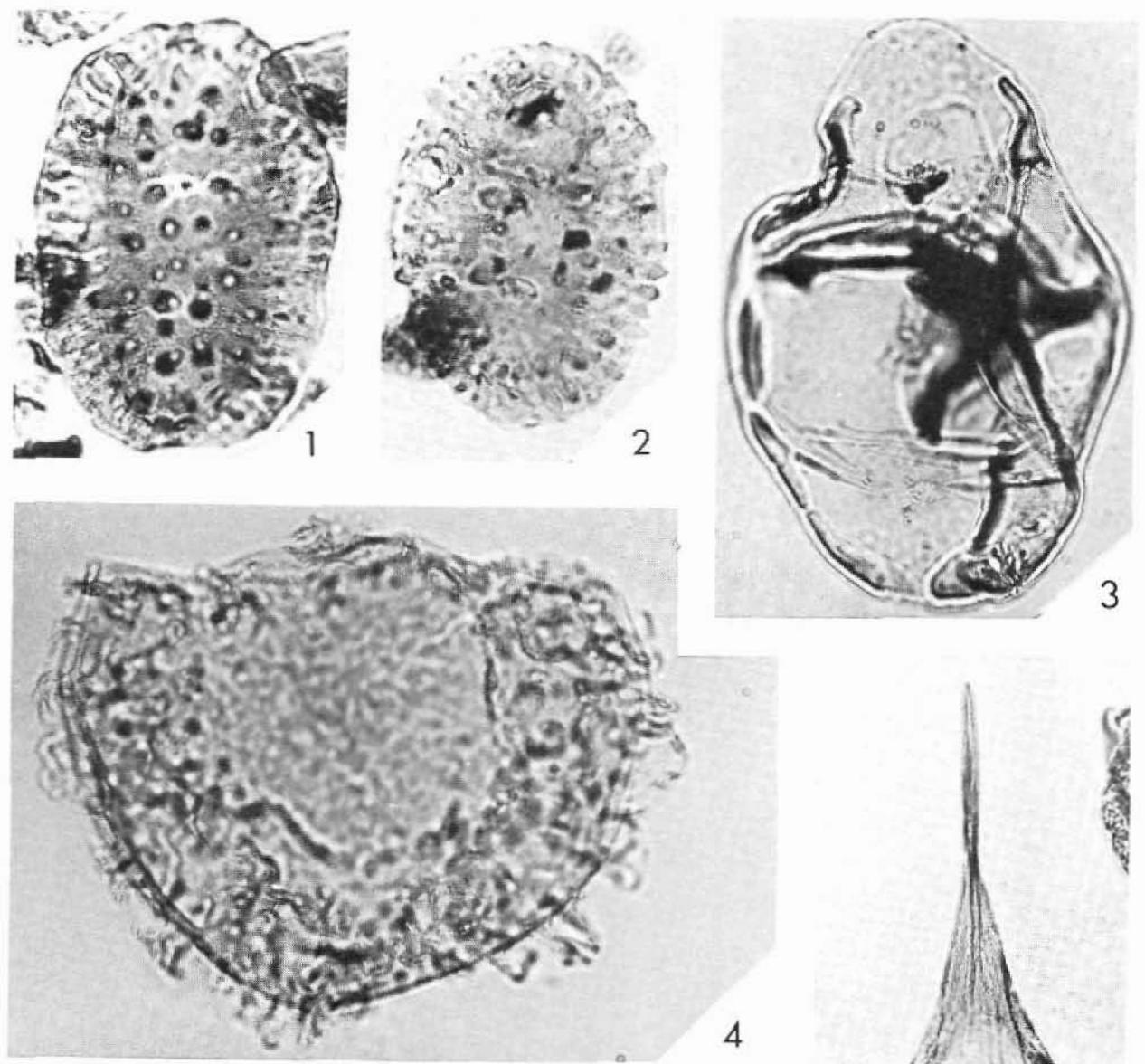

4
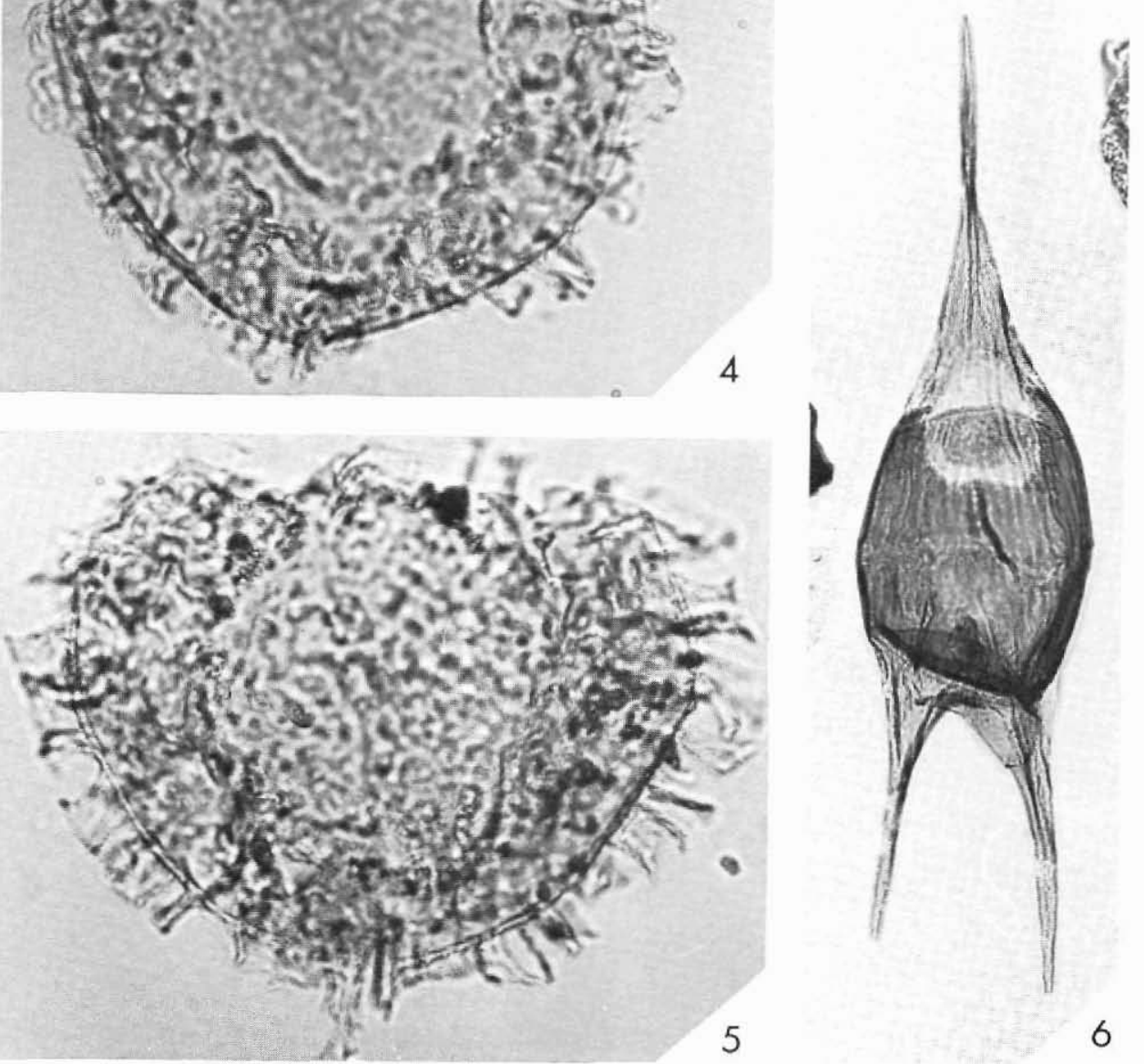


\section{Plate 5}

Magnification $\times 500$, Phase contrast

Illustrations of selected palynomorphs from concretions from the 'Oyster-ammonite Conglomerate', Agatdalen.

Deflandrea diebeli Alberti.

Fig. 1. from GGU 210640 (MGUH 15120, Prep. G259/F8, 19.7, 95.2).

Trithyrodinium sp.

Fig. 2. from GGU 210647 (MGUH 15121, Prep. G266/F8, 33.2, 108.5).

Hystrichosphaeridium sp. A. Williams \& Bujak 1977 from GGU 210647.

Fig. 3. (MGUH 15122, Prep. G266/F8, 32.0, 96.3).

Fig. 4. (MGUH 15123, Prep. G266/F8, 30.9, 92.7).

Fig. 5. (MGUH 15124, Prep. G266/F8, 28.7, 92.8).

Paleoperidinium pyrophorum (Ehrenberg) Sarjeant from GGU 210640.

Fig. 6. (MGUH 15125, Prep. G259/F8, 30.3, 105.3).

Fig. 7. (MGUH 15126, Prep. G259/F8, 19.7, 110.7). 

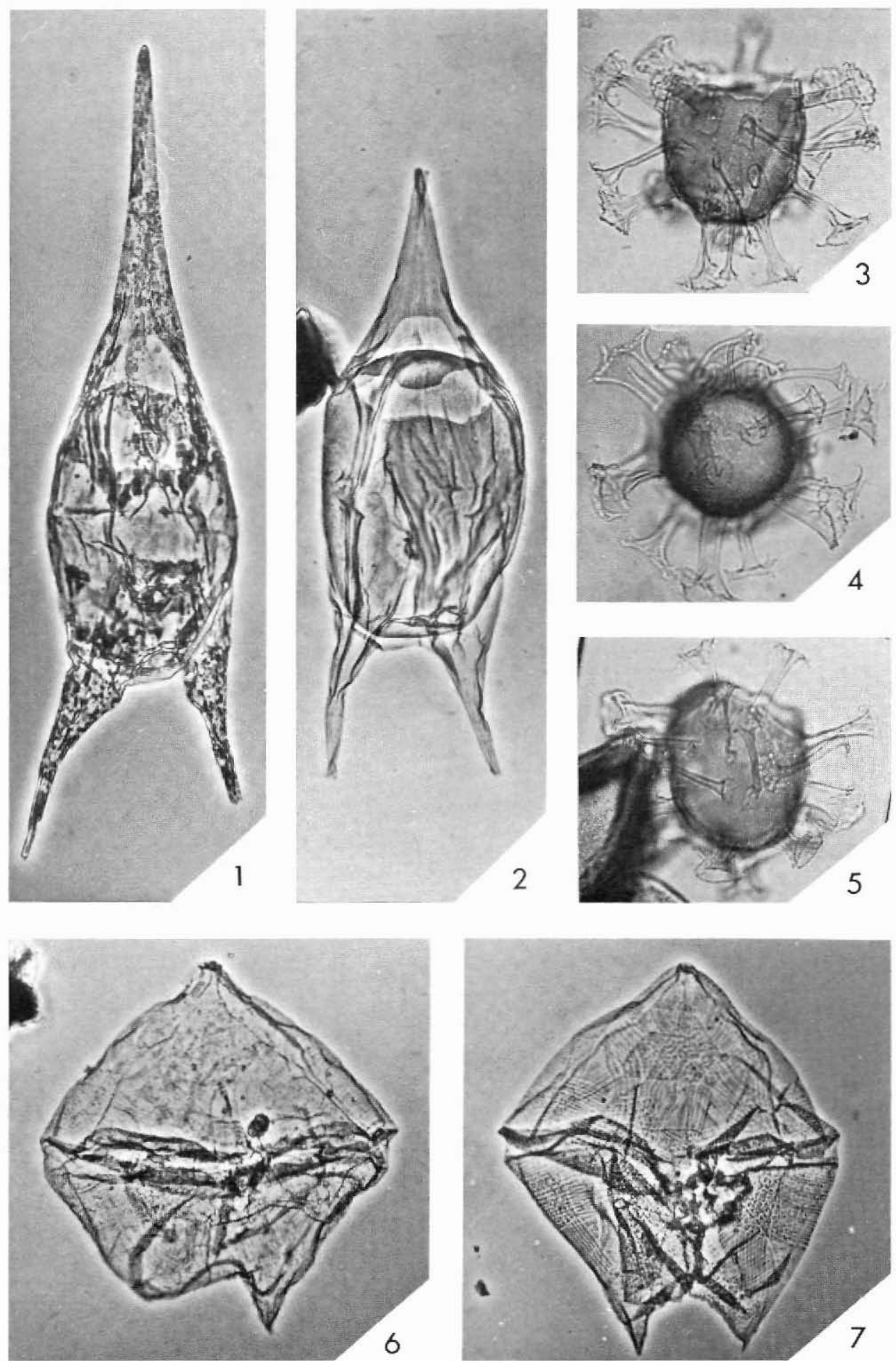